\title{
Effect of Certain Biocides on Fusarium Wilt Disease and Their Effect on Gene Expression Alterations in Tomato Plants
}

\section{El-Fawy, M.M. ' A.S. Saeed ${ }^{1}$; B.E.S. Abdel-Fatah ${ }^{2}$; Heidi I.G. Abo-Elnaga ${ }^{3}$ and A.M. Amein ${ }^{3}$}

${ }^{1}$ Agriculture Botany Dept., (Plant Pathol. Branch) Fac. of Agric., Al-Azhar Univ., Assiut, Egypt

${ }^{2}$ Genetics Dept., Fac. of Agric., Assiut Univ., Assiut, Egypt

${ }^{3}$ Plant Pathol. Dept., Fac. of Agric., Assiut Univ., Assiut, Egypt

Received on: $10 / 6 / 2018$

Accepted for publication on: 13/6/2018

\section{Abstract}

This study evaluated the efficacy of two commercial biocides, i.e. Bio-Zeid (Trichoderma album) and Bio-Arc (Bacillus megaterium) against Fusarium wilt disease of tomato caused by Fusarium oxysporum f. sp. lycopersici (FOL) and F. solani $(F S)$. Application of these biocides as soil treatment significantly $(\mathrm{P}=0.05)$ reduced the percentage of the disease severity of tomato wilt caused by both pathogens under greenhouse conditions at growing seasons 2016 and 2017 when compared to the control treatment. Untreated and treated infected tomato plants (Super strain B cv.) with the tested products were subjected to study the alterations in gene expression using protein profile and four different isozymes(esterase, peroxidase, chitinase and Superoxide Dismutase isozyme) systems. Treated tomato plants showed differences in protein and isozymes banding patterns compared to untreated plants. Two new protein bands at molecular weight $47.2 \mathrm{KD}$ and $16.3 \mathrm{KD}$ were appeared in all infected plants treated with Bio-Zeid and Bio-Arc while, not appeared in control plant. This indicates that these treatments were able to induced new protein bands which increase resistance in tomato plants to Fusarium wilt infection. All treatments were able to induced new protein bands patterns which increasing resistance to Fusarium wilt, but treatment with Bio-Arc was the best because it induced the higher numbers of new protein bands. At the same time, new esterase band (EST5a), peroxidase (PRX-4a), chitinase (Chit-5b) and Superoxide Dismutase isozyme (SOD-1a) bands were detected in all treatments while not appeared in the control.

Keywords: Fusarium wilt, Tomato, Biological control, Trichoderma album, Bacillus megaterium, Protein electrophoresis, Isozymes.

\section{Introduction}

Tomato (Lycopersicon esculentum Mill.) is an important vegetable crop in Egypt and the world and it's the second most consumed vegetable crop next to potato (Srivastava et al., 2010). Fusarium wilt disease is a destructive disease of tomato in major growing regions worldwide and causes severe yield loses in field and greenhouse (Girhepuje and Shinde, 2011; Bawa, 2016). This disease caused by Fusarium oxysporum f. sp. lycopersici and Fusarium solani and reduces yield in this crop (Ajilogba and Babalola, 2013 and Manikandan et al., 2018).

Bio-control agents can induce resistance in plants against many pathogens such as fungi (Bokhari and Perveen, 2012), viruses (Maurhofer et al., 1994) and bacteria (Park and Kloepper, 2000). Jayalakshmi et al. (2009) reported that the activity of 
both polyphenoloxidase and peroxidase enzymes increased after the treatment with $T$. harzianum. Mohamed et al. (2008) found that application of Rhizo-N, Plant guard and culture filtrate of $T$. harzianum and Chaetomium globosum as a soil treatment or seed dressing in pot trials increased cumin seed germination and reduced the incidence of cumin wilt disease. The application of $B$. subtilis to the soil increased peroxidases activity in tomato plants at a level comparable to spraying acibenzolar-S-methyl (Araujo and Menezes, 2009).

The ability of Trichoderma to reduce diseases caused by soil borne pathogens is well known and it is related to the antagonistic properties of Trichoderma, which involve parasitism and lysis of pathogenic fungi and competition for limiting factors in the rhizosphere mainly iron and carbon (Sivan and Chet, 1986 and Benitez et al., 2004). Bio-Arc, Bio-zeid and salicylic acid as a foliar treatment or seed soaking lead to provide protection of alfalfa plants against downy mildew, rust, root rot and wilt disease (Morsy et al., 2011). Another mechanism has been suggested by Kleifeld and Chet (1992) who found that Trichoderma induced resistance in host plants to fungal attack. There are several evidences which supported that Trichoderma spp. were able to induce the defense mechanisms in several plants (Vinale et al., 2008; Brotman et al., 2012). Yedidia et al., (1999) showed that Trichoderma initiated increase in peroxidase and chitinase activities.

The objectives of this study were to evaluate the efficacy of Bio-Zeid and Bio-Arc as soil treatment to control Fusarium wilt disease of tomato and their effect on gene expression alterations using protein and certain isozymes profiling.

\section{Materials and Methods}

Isolation of causal fungal pathogens:

Two isolates of $F$. oxysporum $\mathrm{f}$. sp. lycopersici (1 and 2 ) and $F$. solani isolates (1 and 2$)$ used in this study were isolated from tomato plants, showing typical symptoms of Fusarium wilt disease as mentioned by El-Fawy and Ahmed (2015). Identification of the fungal isolates of Fusarium species was carried out by using the morphological characteristics of mycelia and spores as described by Nelson et al. (1983) and Leslie and Summerell, (2006) then confirmed by Assiut University Mycological center (AUMC). Pure cultures of all identified fungi were maintained at $4^{\circ} \mathrm{C}$ PDA slants until use.

\section{Pathogenicity tests}

Inocula of the isolated fungi were prepared by Inoculation sterilized bottle $500 \mathrm{ml}$, containing barely medium (75 gm barely +25 gm clean sand +2 gm sucrose +0.1 $\mathrm{gm}$ yeast $+100 \mathrm{ml}$ water) and autoclaved at $121^{\circ} \mathrm{C}$ for $20^{\circ} \mathrm{C}$ minute on two consecutive days (Abd Elmoneem, 1996). Two isolates of $F O L$ (1 and 2) and two isolates of FS (1 and 2) were taken from 5-7 days old cultures on PDA medium was aseptically introduced into the bottle and allowed to grow for 3 weeks. Pathogenicity test was carried out by using autoclaved clay loam soil. Batches of autoclaved soil were infested separately with inoculums of 
each isolate at the rate $1 \%(10 \mathrm{gm} / \mathrm{kg})$ of soil dispersed in $30 \mathrm{~cm}$ diameter earthern pots, and then pots were planted with four transplantings of tomato from both cultivars (Super Jakal and 745). Four replicates were used for each treatment. In the control treatment sterilized barely medium was mixed with the soil at the rate $1 \% \quad(10 \mathrm{gm} / \mathrm{kg})$ of soil. Disease severity was recorded after 90 days of transplanting. Disease severity of wilted plants was recorded as described by (Paz-Lago et al., 2000) using the following scale of $0-5$ degrees: $0=$ foliage or not damaged root, $1=$ wilting or damaged root $(20 \%), 2=$ wilting or damaged root $(40 \%), 3=$ wilting or damaged root $(60 \%), 4=$ wilting or damaged root $(80 \%)$ and $5=$ wilting or damaged root $(100 \%)$ or plant death.

Disease severity $(\%)=\sum[(\mathrm{n} \times \mathrm{V})$ $15 \times \mathrm{N})] \times 100$

where, $\mathrm{n}=$ number of plants in each infection category, $\mathrm{V}=$ numerical values of infection categories, $\mathrm{N}=$ total number of plants examined and $5=$ constant, the highest numerical value.

\section{Effect of Bio-Zeid and Bio-Arc as soil treatment on Fusarium wilt disease of tomato under greenhouse conditions:}

This experiment was carried out in 2016 and 2017 in the greenhouse of Plant Pathology Dept., Faculty of Agriculture, Assiut University. Inocula of FOL (1 and 2) and FS (1 and 2) were grown on barley medium $(150 \mathrm{~g}$ barley $+50 \mathrm{~g}$ clean sand $+4 \mathrm{~g}$ glucose +0.2 g yeast extract +200 $\mathrm{mL}$ water) in $500-\mathrm{mL}$ flasks and incubated at $25^{\circ} \mathrm{C}$ for 15 days (Abd El-moneem,1996). Sterilized earthern pots $(30 \mathrm{~cm}$ in diameter) were filled with sterilized soil and infested by the isolates at the rate of $1 \%(\mathrm{w} / \mathrm{w})$ one week before planting. Each pot was sown with four transplantings of tomato cultivar (Super Strain B). Two commercial biocides namely, BioZeid (Trichoderma album) $10 \times 10^{8}$ spores/g and Bio-Arc (Bacillus megaterium) $25 \times 10^{8} \mathrm{CFU} / \mathrm{g}$ obtained from Biological Control Unit, Plant Pathology Institute preparation contains active ingredient biocides to the recommendations of the Ministry of Agriculture, Egypt. These biocides are produced by the local company producing the organic biotechnology. These biocides were added to the soil pots with irrigated water at concentration of $1 \mathrm{~g} / \mathrm{L}$ water. These treatments were applied twice (two weeks between each treatment). Four pots were used for each treatment as replicates and untreated pots with the isolates were used as control. Disease severity was recorded after 90 days of transplanting tomato plants as mentioned before.

\section{Biochemical analysis}

Proteins or enzymes were extracted using the method reported by (Maria and Gache,2004) by crushing $1.0 \mathrm{~g}$ of sample tissue (2-3 leaves from each of control and treatment plants) in $1.0 \mathrm{ml}$ extraction buffer $(0.1 \mathrm{M}$ Tris- $\mathrm{HCl}+2 \mathrm{mM}$ EDTA, pH 7.8). Then, the samples centrifuged for 25 minutes at 10.000 $\mathrm{rpm}$ and $4^{\circ} \mathrm{C}$. $100 \mu 1$ of the supernatant was mixed by $100 \mu 1$ of loading dye for isozymes the samples loaded directly in the electrophoresis. Meanwhile, protein samples were incubated in water path at $100{ }^{\circ} \mathrm{C}$ for five minutes for protein denaturation, 
then loaded in the electrophoresis. $100 \mu \mathrm{l}$ per sample are then loaded directly into the wells with a syringe. Electrophoresis was performed at a constant voltage of $100 \mathrm{~V}$ initially for $1 \mathrm{~h}$ and $180 \mathrm{~V}$ to complete electrophoresis.

\section{Isozymes Staining}

The staining protocols were according to Guidkema and Sherman (1980) for peroxidase (E.C.1.11.1.7); for esterase (E.C.3.1.1.2) according to (Tanksley and Orton, (1986); for Superoxide Dismutase (SOD, E.C. 1.15.1.1) was according to Wang, (1996) and Chitinase (E.C.3.2.1.14) Staining gel was done according to (Shen et al., (1991).

\section{Protein staining}

Proteins were staining 4 hours with Comassie Brilliant Blue (0.025\% Comassie Brilliant Blue R$250,40 \%$ methanol and $7 \%$ acetic acid). Then, gels were distained for one hour in a mixture of $50 \%$ methanol and $10 \%$ acetic acid. Thereafter, the gels transferred to a destainer filled with $7 \%$ acetic acid and $5 \%$ methanol until the background is clear.

\section{Biochemical data analysis}

For isoenzymes: The number of isozyme bands was recorded and their relative mobility (RF) was calculating according to the formula:

$\mathrm{RF}=\frac{\text { Distance travelled by the band }}{\text { distance traveled by the tracking dye }}$
For protein: Data were obtained by scanning densitometer GS 300 (Hoffer) of protein profiles. The molecular weight of protein bands were determined against protein marker using GS 365 electrophoresis data system program version 3.01 (Microsoft Windows@ @ersion).

Statistical analysis:

Data were analyzed using the MSTAT-C (1991) program version 2.10. Means of treatments were differentiated using Least significant difference (LSD) at $\mathrm{P}=0.05$ (Gomez and Gomez, 1984).

\section{Results}

Pathogenicity tests of some Fusarium species isolates on Super Jakal and 745 cultivars under greenhouse conditions during growing.

Data presented in Table (1) show that all the tested isolates of FOL and FS were able to infect tomato Super Jakal and 745 cultivars and produced typical symptoms of Fusarium wilt disease. The tested isolates significantly reduced the disease severity percentage of $(\mathrm{P}=0.05)$ compared to the control. The highest percentage of disease severity was caused by $F O L$ isolate No. 1 on Super Jakal cultivar $(78.10 \%)$, followed by $F S$ isolate No. $2(43.75 \%)$. Meanwhile, FOL isolate No. $2(28.10 \%)$ followed by FS No. 1 (31.25\%) on 745 cultivar. 
Table 1. Pathogenicity test of FOL and FS isolates on Super Jakal and 745 cultivars during growing seasons under greenhouse conditions.

\begin{tabular}{|l|c|c|}
\hline \multicolumn{2}{|c|}{ İsolates No. } & \multicolumn{2}{c|}{ Disease severity \% } \\
\cline { 2 - 3 } & Super Jakal & $\mathbf{7 4 5}$ \\
\hline FOL (1) & 78.10 & 37.50 \\
\hline FOL (2) & 34.30 & 28.10 \\
\hline FS (1) & 40.60 & 31.25 \\
\hline FS (2) & 43.75 & 34.37 \\
\hline Control & \multicolumn{2}{|c|}{10.03} \\
\hline L.S.D. at 5\% for: & \multicolumn{2}{|c|}{6.35} \\
Isolates (I) & \multicolumn{2}{|c|}{14.19} \\
Cultivars (C) & \multicolumn{2}{|c|}{} \\
Interaction (I×C) & \multicolumn{2}{|c|}{0.00} \\
\hline
\end{tabular}

Effect of soil application with BioZeid and Bio-Arc on Fusarium wilt disease in tomato under greenhouse conditions during growing seasons 2016 and 2017.

Results presented in Table (2) indicate that all tested two biocides (Bio-Zeid and Bio-Arc) significantly reduced the percentage of disease severity of tomato wilt disease caused by $F O L$ and $F S$ both tested seasons compared to the control. Bio-Arc showed higher decreased in percentage of disease severity than Bio-Zeid which it recorded (25 and 9.30\%) and (29.10 and $11.70 \%$ ) with $F O L$ and $F S$ during growing seasons 2016 and 2017 respectively. During both tested seasons Bio-Zeid was the lowest effect in reducing the percentage of disease severity recorded $(34.3$ and $28.10 \%)$ and (32.20 and $25.7 \%)$ with $F O L$ and $F S$.

Table 2. Effect of Bio-Zeid and Bio-Arc on Fusarium wilt disease of tomato under greenhouse conditions during growing seasons 2016 and 2017.

\begin{tabular}{|c|c|c|c|c|c|c|c|c|c|c|c|c|}
\hline \multirow{4}{*}{ Treatments } & \multicolumn{12}{|c|}{ Disease severity \% } \\
\hline & \multicolumn{6}{|c|}{ Season 2016} & \multicolumn{6}{|c|}{ Season 2017} \\
\hline & \multicolumn{3}{|c|}{$\begin{array}{l}\text { F. o. f. sp. } \\
\text { lycopersici }\end{array}$} & \multicolumn{3}{|c|}{ F. solani } & \multicolumn{3}{|c|}{$\begin{array}{l}\text { F. o. f. sp. } \\
\text { lycopersici }\end{array}$} & \multicolumn{3}{|c|}{ F. solani } \\
\hline & Iso.1 & Iso. 2 & Mean & Iso.1 & Iso. 2 & Mean & Iso. 1 & Iso. 2 & Mean & Iso. 1 & Iso. 2 & Mean \\
\hline Bio-Zeid & 35.37 & 33.30 & 34.33 & 31.22 & 33.30 & 32.26 & 28.10 & 28.10 & 28.10 & 26.52 & 24.97 & 25.74 \\
\hline Bio-Arc & 25.00 & 25.00 & 25.00 & 27.07 & 32.27 & 29.67 & 18.72 & 20.30 & 19.51 & 23.42 & 23.40 & 23.41 \\
\hline Control & 56.22 & 54.15 & 55.18 & 60.37 & 79.12 & 69.74 & 45.20 & 48.40 & 46.80 & 54.65 & 57.77 & 56.21 \\
\hline Mean & 35.39 & 34.36 & 34.87 & 36.95 & 43.46 & 40.20 & 25.34 & 26.53 & 25.94 & 28.87 & 29.66 & 29.26 \\
\hline \multicolumn{3}{|c|}{ L.S.D. at $5 \%$ for } & \multirow{2}{*}{\multicolumn{2}{|c|}{4.11}} & & & \multirow{2}{*}{\multicolumn{6}{|c|}{2.79}} \\
\hline Treatments & \multicolumn{2}{|l|}{ (T) } & & & & & & & & & & \\
\hline Fungi & \multirow{2}{*}{\multicolumn{2}{|c|}{ (I) }} & \multicolumn{2}{|c|}{2.91} & & & \multicolumn{6}{|c|}{1.97} \\
\hline Isolates & & & \multicolumn{2}{|c|}{2.21} & & & \multicolumn{6}{|c|}{2.20} \\
\hline Interaction & \multicolumn{2}{|l|}{ (I) } & \multicolumn{2}{|c|}{$\begin{array}{l}2.21 \\
6.25\end{array}$} & & & & & \\
\hline
\end{tabular}

\section{Biochemical markers:} Protein profiling:

Protein profiling was done to determine whether some new protein was associated with induced resistance to pathogenic $F O L$ (1 and 2 ) and $F S$ (1 and 2) in resistance tomato genotype (Super strain B) 
treated with Bio-Zeid and Bio-Arc. SDS-PAGE is used for finding the banding pattern of proteins. It has been found that the banding patterns of protein control and two treatments are variable (Table 3 and Figure 1). The SDS PAGE protein profile of total soluble protein from infected plants treated with two treatments showed differences in band pattern when compared with control. In general, control plant exhibit 20 protein bands, these bands were common in all treatments except protein banding at molecular weight 28.2 KD which disappear in all infected plants with $F$. oxysporum (1). Four Protein bands at molecular weight $47.2 \mathrm{KD}, 38.2 \mathrm{KD}, 16.3 \mathrm{KD}$ and $15.6 \mathrm{KD}$ appeared only in treated plants. Two new protein bands at molecular weight $47.2 \mathrm{KD}$ and 16.3
$\mathrm{KD}$ were appeared in all infected plants treated with Bio-zeid and BioArc treatments while, not appeared in control plant. This indicates that the two treatments were able to induced new protein banding which increase resistance in tomato plants. New protein band at molecular weight 38.2 $\mathrm{KD}$ and $15.6 \mathrm{KD}$ were detected in all plants treatment with Bio-Arec while not appeared in control and Bio-zeid treatment; this indicates that treatment with Bio-Arc increasing resistance to Fusarium infection through induced new protein patterns. These results revealed that all treatment were able to induced new protein banding patterns which increasing resistance to Fusarium, Bio-Arc treatment was the best because exhibited higher effect than Bio-zeid.

Table 3. The electrophoretic banding patterns of Protein

\begin{tabular}{|c|c|c|c|c|c|c|c|c|c|c|}
\hline \multirow[b]{2}{*}{ No. } & \multirow[b]{2}{*}{ MW } & \multirow[b]{2}{*}{ Cont. } & \multicolumn{4}{|c|}{ Bio-Zeid } & \multicolumn{4}{|c|}{ Bio-Arc } \\
\hline & & & $\begin{array}{c}\text { FOL } \\
(\text { Iso.1) }\end{array}$ & $\begin{array}{c}F O L \\
\text { (Iso.2) }\end{array}$ & $\begin{array}{c}F S \\
(\text { Iso.1) }\end{array}$ & $\begin{array}{c}F S \\
\text { (Iso.2) }\end{array}$ & $\begin{array}{c}\text { FOL } \\
\text { (Iso.1) }\end{array}$ & $\begin{array}{c}\text { FOL } \\
\text { (Iso.2) }\end{array}$ & $\begin{array}{c}F S \\
\text { (Iso.1) }\end{array}$ & $\begin{array}{c}F S \\
\text { (Iso. } \\
\text { 2) }\end{array}$ \\
\hline 1 & 63.5 & + & + & + & + & + & + & + & + & + \\
\hline 2 & 61.6 & + & + & + & + & + & + & + & + & + \\
\hline 3 & 57.1 & + & + & + & + & + & + & + & + & + \\
\hline 4 & 52.1 & + & + & + & + & + & + & + & + & + \\
\hline 5 & 47.2 & - & + & + & + & + & + & + & + & + \\
\hline 6 & 44.1 & + & + & + & + & + & + & + & + & + \\
\hline 7 & 42.2 & + & + & + & + & + & + & + & + & + \\
\hline 8 & 38.2 & - & - & - & - & - & + & + & + & + \\
\hline 9 & 37.0 & + & + & + & + & + & + & + & + & + \\
\hline 10 & 35.1 & + & + & + & + & + & + & + & + & + \\
\hline 11 & 33.2 & + & + & + & + & + & + & + & + & + \\
\hline 12 & 32.3 & + & + & + & + & + & + & + & + & + \\
\hline 13 & 28.2 & + & - & + & + & + & - & + & + & + \\
\hline 14 & 26.4 & + & + & + & + & + & + & + & + & + \\
\hline 15 & 24.1 & + & + & + & + & + & + & + & + & + \\
\hline 16 & 20.2 & + & + & + & + & + & + & + & + & + \\
\hline 17 & \begin{tabular}{|l|}
18.8 \\
\end{tabular} & + & + & + & + & + & + & + & + & + \\
\hline 18 & $\mathbf{1 7 . 1}$ & + & + & + & + & + & + & + & + & + \\
\hline 19 & $\begin{array}{l}16.3 \\
\end{array}$ & - & + & + & + & + & + & + & + & + \\
\hline 20 & 15.6 & - & - & - & - & - & + & + & + & + \\
\hline 21 & 14.8 & + & + & + & + & + & + & + & + & + \\
\hline 22 & 12.8 & + & + & + & + & + & + & + & + & + \\
\hline 23 & 10.1 & + & + & + & + & + & + & + & + & + \\
\hline 24 & 7.4 & + & + & + & + & + & + & + & + & + \\
\hline
\end{tabular}




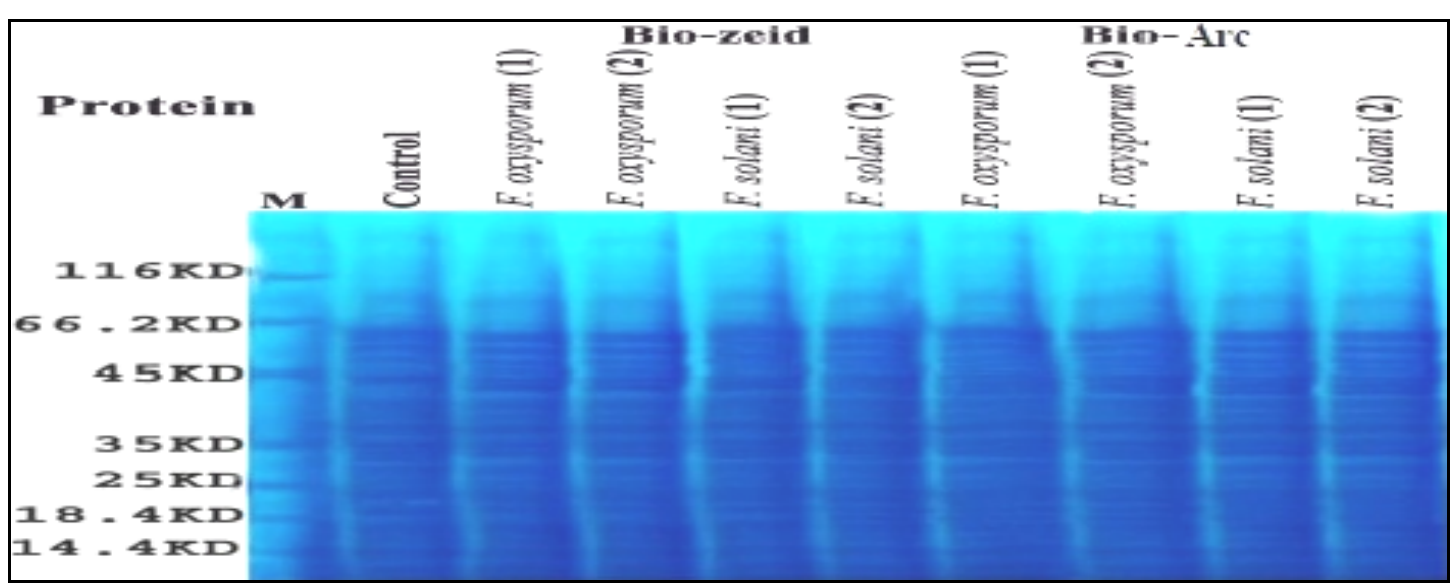

Fig. 1: Electrophoretic pattern of total soluble proteins detected in extracts of tomato plant (Super strain B), cultivated in infested soil with FOL (1 and 2) and FS (1 and 2) and treated with Bio-Zeid and Bio-Arc.

\section{Biochemical isozyme markers:}

Tomato infected plants with $F$. oxysporum (isolate 1 and 2), F. solani (isolate 1 and 2), $F$. oxysporum (2) and $F$. solani $(2)$ showing variability in number, relative mobility and density of isozymes compared with control plants.

\section{Esterase isozyme profiles (EST):}

The total number of esterase isozymes was nine bands ranged from $\mathrm{Rf}=0.32(\mathrm{EST}-1 \mathrm{a})$ to $\mathrm{RF}=0.95$ (EST-7) in Table (4) and Fig (2a). Infected plants treated with Bio-zeid and Bio-Arc treatments showed variation in number bands compared with control. Seven esterase isozyme bands were common between the control and all infected plants treated with two biocides treatments. New esterase band EST-5a at Rf $=0.77$ was appeared in all treatments and appear in the control. Isozyme band EST-1a at $\mathrm{Rf}=0.32$ appeared only in infected plants treated with Bio-Arc while not appeared in control and Bio-zeid treatment.

\section{Peroxidase isozymes activity (PRX):}

The total numbers of peroxidase isozymes were eight bands ranged from PRX-1 $(\mathrm{Rf}=0.35)$ to $\mathrm{PRX}-8$
$(R F=0.92)($ Table 4 and Fig.2b). Five out of eight bands were common bands with percentage $62.5 \%$ at PRX-1 $(\mathrm{Rf}=0.35), \quad \mathrm{PRX}-2 \quad(\mathrm{Rf}=$ 0.48), PRX-3 (Rf=0.77), PRX-4 (Rf= $0.85)$ and PRX-5 $(\mathrm{Rf}=0.92)$ these bands related to tomato plants. Peroxidase isozyme band PRE-1a with $\mathrm{Rf}=0.4$ induced only in infected plants treated with Bio-Arc but not found in control and Bio-zeid treatment. New isozyme peroxidase bands PRX-2a $(\mathrm{Rf}=0.53)$ and PRX4a $(\mathrm{Rf}=0.8)$ were detected in infected plants treated with both Bio-zeid and Bio-Arc treatments.

Chitinase isozymes activity (Chit.):

Table (3) and Figure (2c) represents numbers of Chitinase bands detected in tomato plants infected with FOL isolates No. 1 and 2 and isolates No. 1 and 2 of $F S$ and treated with Bio-Zeid and Bio-Arc by electrophoretic analysis. Data show that different chitinase isozyme bands were found. A total of ten bands were detected with $\mathrm{Rf}$ ranged from 0.140.97 , five of them were common bands between control and all treatments with percentage $50 \%$, while the other bands $50 \%$ were 
polymorphic bands. Both of Bio-zeid and Bio-Arc treatments induced three new chitinase bands Chit-1a (Rf= $0.23)$, Chit-5a $(\mathrm{Rf}=0.83)$ and Chit-5b $(\mathrm{Rf}=0.89)$. The two Chitinase bands Chit-1b $(\mathrm{Rf}=0.31)$ and Chit-3a $(\mathrm{Rf}=$ 0.54 ) were expressed only in infected plants treated with Bio-Arc while not expressed in control and infected plants treated with Bio-zeid treatment.

Superoxide Dismutase (SOD, E.C. 1.15.1.1):
Superoxide Dismutase bands SOD-1 $(\mathrm{Rf}=0.32)$, SOD-3 $(\mathrm{Rf}=0.6)$ and SOD-5 $(\mathrm{Rf}=0.95)$ were monomorphic and common in control and all treatment plants. Superoxide Dismutase band SOD-1a at $\mathrm{Rf}=0.47$ was induced in all infected plants treated with both Bio-zeid and BioArc treatments. New isozyme band SOD-3a at $\mathrm{Rf}=0.72$ was expressed only in infected plant treated with Bio-Arec (Table 4 and Fig. 2d).

Table 4. The electrophoretic banding patterns of four isozymes (EST, PER, Chit and SOD) in extracts of tomato plant (Super strain B), cultivated in infested soil with FOL isolates No. 1 and 2 and FS No. 1 and 2 and treated with BioZeid and Bio-Arc.

\begin{tabular}{|c|c|c|c|c|c|c|c|c|c|c|c|}
\hline \multirow[b]{2}{*}{ No } & \multirow[b]{2}{*}{ IOSZYMES } & \multirow[b]{2}{*}{ Rf } & \multirow[b]{2}{*}{ Cont. } & \multicolumn{4}{|c|}{ Bio Zeid } & \multicolumn{4}{|c|}{ Bio Arc } \\
\hline & & & & $\begin{array}{c}\text { FOL } \\
\text { (Iso. 1) } \\
\end{array}$ & $\begin{array}{c}\text { FOL } \\
\text { (Iso. 2) } \\
\end{array}$ & $\begin{array}{c}F S \\
\text { (Iso. 1) } \\
\end{array}$ & $\begin{array}{c}F S \\
\text { (Iso. 2) } \\
\end{array}$ & $\begin{array}{c}\text { FOL } \\
\text { (Iso. 1) } \\
\end{array}$ & $\begin{array}{c}\text { FOL } \\
\text { (Iso. 2) } \\
\end{array}$ & $\begin{array}{c}F S \\
\text { (Iso. 1) } \\
\end{array}$ & $\begin{array}{c}F S \\
\text { (Iss. 2) } \\
\end{array}$ \\
\hline 1 & EST-1a & 0.32 & - & - & - & - & - & + & + & + & + \\
\hline 2 & EST-1 & 0.37 & + & + & + & + & + & + & + & + & + \\
\hline 3 & EST-2 & 0.42 & + & + & + & + & + & + & + & + & + \\
\hline 4 & EST-3 & 0.46 & + & + & + & + & + & + & + & + & + \\
\hline 5 & EST-4 & 0.68 & + & + & + & + & + & + & + & + & + \\
\hline 6 & EST-5 & 0.72 & + & + & + & + & + & + & + & + & + \\
\hline 7 & EST-5a & 0.77 & - & + & + & + & + & + & + & + & + \\
\hline 8 & EST-6 & 0.89 & + & + & + & + & + & + & + & + & + \\
\hline 9 & EST-7 & 0.95 & + & + & + & + & + & + & + & + & + \\
\hline \multirow[b]{2}{*}{ No } & \multirow[b]{2}{*}{ IOSZYMES } & \multirow[b]{2}{*}{ Rf } & \multirow[b]{2}{*}{ Cont. } & \multicolumn{4}{|c|}{ Bio Zeid } & \multicolumn{4}{|c|}{ Bio Arc } \\
\hline & & & & $\begin{array}{c}\text { FOL } \\
\text { (Iso. 1) }\end{array}$ & $\begin{array}{c}\text { FOL } \\
\text { (Iso. 2) }\end{array}$ & $\begin{array}{c}\text { FOL } \\
\text { (Iso. 1) }\end{array}$ & $\begin{array}{c}F O L \\
\text { (Iso. 2) } \\
\end{array}$ & $\begin{array}{c}\text { FOL } \\
\text { (Iso. 1) }\end{array}$ & $\begin{array}{c}\text { FOL } \\
\text { (Iso. 2) }\end{array}$ & $\begin{array}{c}\text { FOL } \\
\text { (Iso. 1) }\end{array}$ & $\begin{array}{c}\text { FOL } \\
\text { (Iso. 2) }\end{array}$ \\
\hline 1 & PRX-1 & 0.35 & + & + & + & + & + & + & + & + & + \\
\hline 2 & PRX-1a & 0.4 & - & - & - & - & - & + & + & + & + \\
\hline 3 & PRX-2 & 0.48 & + & + & + & + & + & + & + & + & + \\
\hline 4 & PRX-2a & 0.53 & - & + & + & + & + & + & + & + & + \\
\hline 5 & PRX-3 & 0.77 & + & + & + & + & + & + & + & + & + \\
\hline 6 & PRX-4a & 0.8 & - & + & + & + & + & + & + & + & + \\
\hline 7 & PRX-4 & 0.85 & + & + & + & + & + & + & + & + & + \\
\hline 8 & PRX-5 & 0.92 & + & + & + & + & + & + & + & + & + \\
\hline \multirow[b]{2}{*}{ No } & \multirow[b]{2}{*}{ IOSZYMES } & \multirow[b]{2}{*}{$\mathbf{R f}$} & \multirow[b]{2}{*}{ Cont. } & \multicolumn{4}{|c|}{ Bio Zeid } & \multicolumn{4}{|c|}{ Bio Arc } \\
\hline & & & & $\begin{array}{c}\text { FOL } \\
\text { (Iso. 1) }\end{array}$ & $\begin{array}{c}\text { FOL } \\
\text { (Iss. 2) }\end{array}$ & $\begin{array}{c}\text { FOL } \\
\text { (Iso. 1) }\end{array}$ & $\begin{array}{c}\text { FOL } \\
\text { (Iso. 2) } \\
\end{array}$ & $\begin{array}{c}\text { FOL } \\
\text { (Iso. 1) }\end{array}$ & $\begin{array}{c}\text { FOL } \\
\text { (Iso. 2) }\end{array}$ & $\begin{array}{c}\text { FOL } \\
\text { (Iso. 1) }\end{array}$ & $\begin{array}{c}\text { FOL } \\
\text { (Isso. 2) }\end{array}$ \\
\hline 1 & Chit-1 & 0.14 & + & + & + & + & + & + & + & + & + \\
\hline 2 & Chit-1a & 0.23 & - & + & + & + & + & + & + & + & + \\
\hline 3 & Chit-1b & 0.31 & - & - & - & - & - & + & + & + & + \\
\hline 4 & Chit-2 & 0.37 & + & + & + & + & + & + & + & + & + \\
\hline 5 & Chit-3 & 0.48 & + & + & + & + & + & + & + & + & + \\
\hline 6 & Chit-3a & 0.54 & - & - & - & - & - & + & + & + & + \\
\hline 7 & Chit-4 & 0.71 & + & + & + & + & + & + & + & + & + \\
\hline 8 & Chit-5a & 0.83 & - & + & + & + & + & + & + & + & + \\
\hline 9 & Chit-5b & 0.89 & - & + & + & + & + & + & + & + & + \\
\hline 10 & Chit-5 & 0.97 & + & + & + & + & + & + & + & + & + \\
\hline \multirow[b]{2}{*}{ No } & \multirow[b]{2}{*}{ IOSZYMES } & \multirow[b]{2}{*}{ Rf } & \multirow[b]{2}{*}{ Cont. } & \multicolumn{4}{|c|}{ Bio Zeid } & & Bic & arc & \\
\hline & & & & $\begin{array}{c}\text { FOL } \\
\text { (Iso. 1) }\end{array}$ & $\begin{array}{c}\text { FOL } \\
\text { (Iso. 2) }\end{array}$ & $\begin{array}{c}\text { FOL } \\
\text { (Iso. 1) }\end{array}$ & $\begin{array}{c}F O L \\
\text { (Iso. 2) }\end{array}$ & $\begin{array}{c}\text { FOL } \\
\text { (Iso. 1) }\end{array}$ & $\begin{array}{c}\text { FOL } \\
\text { (Iso. 2) }\end{array}$ & $\begin{array}{c}\text { FOL } \\
\text { (Iso. 1) }\end{array}$ & $\begin{array}{c}\text { FOL } \\
\text { (Iso. 2) }\end{array}$ \\
\hline 1 & SOD-1 & 0.32 & + & + & + & + & + & + & + & + & + \\
\hline 2 & SOD-1a & 0.47 & - & + & + & + & + & + & + & + & + \\
\hline 3 & SOD-2 & 0.6 & + & + & + & + & + & + & + & + & + \\
\hline 4 & SOD-3a & 0.72 & - & - & - & - & - & + & + & + & + \\
\hline 5 & SOD-3 & 0.95 & + & + & + & + & + & + & + & + & + \\
\hline
\end{tabular}



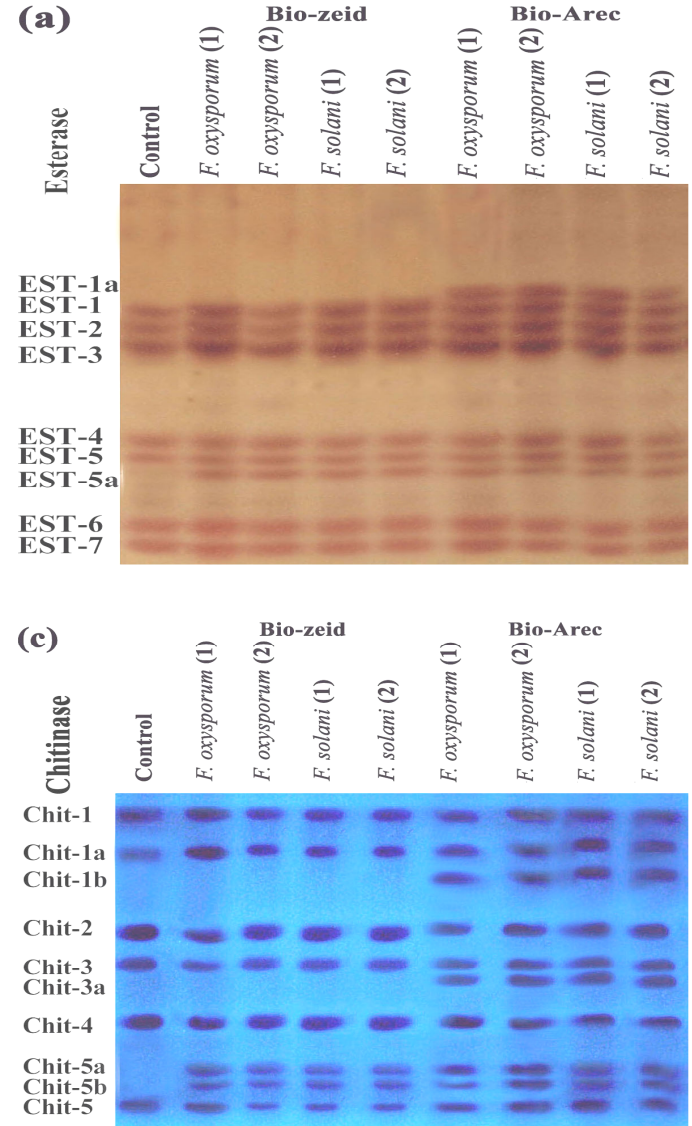

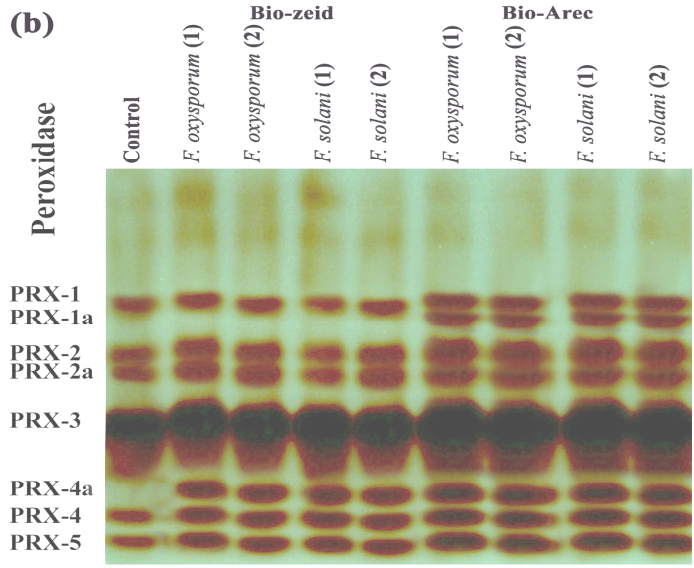

(d)

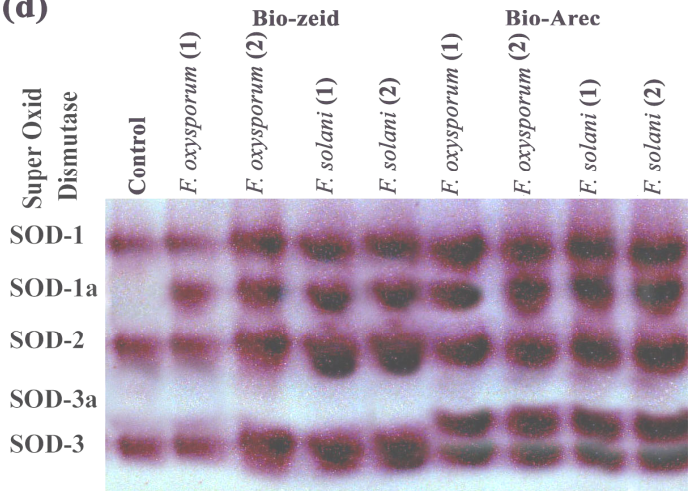

Fig. 2: Electrophoretic pattern of esterase, peroxidase, chitinase and Super Oxide Dismutase isozymes detected in extracts of tomato plant (Super strain B), cultivated in infested soil with FOL No. 1 and 2 and FS No. 1 and 2 and treated with Bio Zeid and Bio Arc.

\section{Discussion}

Tomato wilt disease caused reduction in weight of tomato fruits and productivity (Dursun et al., 2010). This disease is an economically important and a destructive disease of tomato crop in all production areas (Jones et al., 1991 and JabnounKhiareddine et al., 2016).

Application of Bio-Zeid (Trichoderma album) and Bio-Arc (Bacillus megaterium) to infested soil with pathogenic fungi (Fusarium oxysporum f. sp. lycopersici or F. solani) has a beneficial effect, when added to soil with irrigated water. Generally, soil amendment with these bio-control products was effective in decreasing Fusarium wilt disease symptoms on tomato plants. These results are consistent with those reported by Ibrahim (2015) showed that application of biocides (Bio-Arc and Bio-Zeid) as seed dressing reduced percentage of mean infection seedborne fungi such as Alternaria spp., $F$. moniliforme, F. semitectum, F. solani, $F$. oxysporum and Rhizoctonia solani. In this study, Bio-Arc showed higher effect in reducing percentage of disease severity of tomato wilt. Biological control of plant diseases is a result of many different types of interaction among microorganisms and can occur through different mechanisms, which are generally classified 
as parasitism, antibiosis, competition, lytic enzymes, and induced resistance (Pal, 2005). The ability of Trichoderma to reduce diseases caused by soil borne pathogens is well known and it is related to the antagonistic properties of Trichoderma, which involve parasitism and lysis of pathogenic fungi and competitions for limiting factors in the rhizosphere mainly iron and carbon (Sivan and Chet, 1986). In another study, El-Metwally et al., (2010) found that foliar treatment of faba bean plants with BioZeid and Bio-Arc led to maximum reduction of chocolate spot disease severity. Abou-Aly et al., (2008) showed that B. megaterium, B. subtilis, B. coagulans P. fluorescens and Paenibacillus polymyxa exhibited beneficial mechanisms against Fusarium oxysporum f. sp lycopersici and $F$. solani. Treated tomato plants with these compounds showed differences in protein and isozymes banding patterns compared to untreated plants. Two new protein bands at molecular weight $47.2 \mathrm{KD}$ and $16.3 \mathrm{KD}$ were appeared in all infected plants treated with Bio-Zeid and Bio-Arc while, not appeared in the control plants. These results are in agreement with those reported by El-Askary et al. (2003) and Akladious et al., (2015). They showed that new protein bands induced in infected plants treated with the bio-products act as a protein marker in resistance mechanisms; such response allows plants to become more tolerant to the pathogens. In this study, data revealed that treatments with BioZeid and Bio-Arc able to induced new protein banding patterns which increasing resistance to Fusarium wilt, but treatment with Bio-Arc showed higher effect because it induced the higher numbers of new protein bands. At the same time, new esterase band (EST-5a), peroxidase (PRX-2a and PRX-4a), chitinase (Chit-1a, Chit-5a and Chit-5b) and Superoxide Dismutase isozyme (SOD-1a) bands were detected in all treatments while not appear in the control. Prabhukarthikeyan et al., (2017) showed that two protein bands were appeared in treated tomato plants with bio-formulations while, not appeared in untreated control plants.

Data also, indicate that tomato treated with Bio-Zeid and Bio-Arc, showing variability in numbers, relative mobility and density of esterase, chitinase, peroxidase and Super Oxide Dismutase isozymes compared with control plants. These results are in conformity with the results reported by El-Habbaa et al. (2016) they found that application of bio-formulations such as Rhizo-N, Plant guard and Bio-Zeid as a foliar treatment increased activities of peroxidase, polyphenoloxidase and chitinase in grapevine plants compared to the control treatment. In another study, T. viride induced higher levels of defense enzymes such as peroxidase, polyphenol oxidase and phenyl alanine ammonia lyase in black gram during pathogenesis by $F$. oxysporum and $A$. alteranata (Surekha et al., 2014). The increase in the antioxidant enzymes system (Catalase, Ascorbate peroxidase and Glutathione reductase) was associated with resistance to Fusarium wilt in chickpea (Garcia-Limones et al., 2012). Amer et al., (2014) reported 
that application of the bio-control agents could play an important role in inducing partial resistance and exhibit greater potential to protect tomato plants against wilt.

These results revealed that all treatment were able to induced new isozyme bands which increasing resistance to Fusarium, but treatment with Bio-Arc was the best because it induced the highest number of new isozyme bands (12 isozyme bands) compared to Bio-zeid treatment (7 isozyme bands).

\section{References}

Abd-El moneem, K. M. H.; F. A. Saeed; M. A. Sallam and M. A. ELSaide (1996). Effect of micronutrients on incidence of sesame charcoal rootrot and wilt disease complex. Assiut Journal of Agriculture Science, 27 (3): 181-195.

Abou-Aly, H. E. (2008). Evaluation of some rhizobacteria as potent biological control agents in vitro. Annals of Agric. Sc., Moshtohor, 46(4): 81-90.

Ajilogba, C. F. and O. O. Babalola. (2013). Integrated management strategies for tomato Fusarium wilt. Biocontrol Science, 18 (3): 117-127.

Akladious, S. A.; S. I. George and A. A. Medhat (2015). Induction and resistance against Fusarium wilt disease of tomato by using sweet basil (Ocimum basilicum L) extract. Can. J. Plant Sci., 95: 689701.

Amer, M. A., I. A. El-Samra, I. I. AbouEl-Seoud, Sawsan M. El-Abd and N. K. Shawertamimi (2014). Induced systemic resistance in tomato plants against Fusarium wilt disease using biotic inducers. Middle East Journal of Agriculture Research, 3(4): 1090-1103.
Araujo, F.F and D. Menezes (2009). Inducao de resistencia a doencas foliares em tomateiro por indutores biotico (Bacillus subtilis) e abiotico (Acibenzolar-S-Metil). Summa Phytopathologica, 35:169172.

Bawa, I. (2016). Management strategies of Fusarium wilt disease of tomato incited by Fusarium oxysporum $\mathrm{f}$. sp. lycopersici (Sacc.): A review. International Journal of Advanced Academic Research, 5: 32-42.

Benitez T.; A.M. Rincon, M.C. Limon and A.C. Condon (2004). Biocontrol mechanisms of Trichoderma strains. International, Microbiology, 7 (4): 249-260.

Bokhari, N. A. and K. Perveen (2012). Antagonistic action of Trichoderma harzianum and Trichoderma viride against Fusarium solani causing root rot of tomato. Afr.J.Microbiol Res., 6:7193-7197.

Brotman, Y.; J. Lisec; M. Meret; I. Chet; L. Willmitzer and A. Viterbo (2012). Transcript and metabolite analysis of the Trichodermainduced systemic resistance response to Pseudomonas syringae in Arabidopsis thaliana. Microbiology, 158:139-146.

Dursun, A.; M. Ekinci and M.F. Dönmez (2010). Effects of foliar application of plant growth promoting bacterium on chemical contents, yield and growth of tomato ( $L y$ copersicon esculentum L.) and cucumber (Cucumis sativus L.) Pak J Bot., 42:3349-3356.

El-Askary, H. I.; M. R. Meselhy and A. M. Galal (2003). Sesquiterpenes from Cymbopogon proximus. Molecules, 8: 670-677.

El-Fawy, M. M. and M. M. Sh. Ahmed (2015). Effect of soil amendment with activated yeasts on controlling Fusarium and Verticillium wilt and growth 
characters of pepper. Journal of Phytopathology and Pest Management, 2(2): 60-72.

El-Habbaa, G.M.; Abdou, M.M Mahdy; F. G. Mohamed and S.A. ElShaery (2016). Biological and chemical control of grapevine dieback disease and their effect on defense related enzymes. International Journal of Scientific \& Engineering Research, 7 (3): 345351.

El-Metally, M. A.; Kh. M. Ghanem, and K. M. Abd El-Hai (2010). Improving the performance of faba bean and controlling of chocolate spot disease using bio-compounds. Plant Pathology Journal, 9 (4): 169-178.

Garcia-Limones, C., J. A. Navas-Cortes, R. M. Jimenez-Diaz and M. Tena (2012). Induction of antioxidant enzyme system and other oxidant stress markers associated with compatible and incompatible interactions between chickpea (Cicer arietinum L.) and Fusarium oxysporum f. sp. ciceris. Physiol. Mol. Plant Pathol. 61: 325-337.

Girhepuje, P. V. and G. B. Shinde (2011). Transgenic tomato plants expressing a wheat endochitinase gene demonstrate enhanced resistance to Fusarium oxysporum f sp. lycopersici. Plant Cell Tissue and Organ Culture. 105: 243-251.

Gomez, K. A. and A. A. Gomez (1984). Statistical Procedures for Agricultur Research. $2^{\text {nd }}$ Ed. John Willey. New York. 680 pp.

Guidkema, J. A. and L. A. Sherman, (1980). Electrophoretic profiles of cyanobacterial membrane polypeptides showing hemedependent peroxidase activity. Biochim. Biophys. Acta, 637: 189201.

Ibrahim, E.A.M. (2015). Effect of some treatments on seed health and vi- ability of soybean. Plant Pathology Journal, 14 (4): 158-167.

Jabnoun-Khiareddine, H.; R. Abdallah; R. El-Mohamedy, F. AbdelKareem and M. Gueddes-Chahed (2016). Comparative efficacy of potassium salts against soil-borne and air-borne fungi and their ability to suppress tomato wilt and fruit rots. Journal of Microbial and Biochemical Technology, 8: 045055.

Jayalakshmi, S.K.; S. Raju; S. UshaRani; V.I. Benagi and K. Sreeramulu (2009). Trichoderma harzianum $\mathrm{L} 1$ as a potential source for lytic enzymes and elicitor of defense responses in chickpea (Cicer arietinum L.) against wilt disease caused by Fusarium oxysporum f. sp. ciceri. Australian Journal of Crop Science, 3(1): 44-52.

Jones, J. B.; J. P. Jones; R. E. Stall and T. A. Zitter (1991). Compendium of Tomato Diseases. ISBN: 0890541205, $1^{\text {st }}$ Edition, APS Press, New York, 100 PP.

Kleifeld, O. and I. Chet (1992). Trichoderma harzianum interaction with plants and effect on growth response. Plant and Soil, 144: 267272.

Leslie, J. F. and B. A. Summerell,(2006). The Fusarium laboratory manual. Blackwell Professional, Ames, Iowa.

Manikandan, R., S. Harish, G. Karthikeyan and T. Raguchander, (2018). Comparative proteomic analysis of different isolates of Fusarium oxysporum f. sp. lycopersici to exploit the differentially expresse proteins responsible for virulence on tomato. Plants Frontiers in Microbiology, 9: 420-432.

Maria, I. A. and C. Gache (2004). Development of Sea Urchins, Ascidians, and Other Invertebrate 
Deuterostomes: Experimental Approaches. Method in cell biology.

Maurhofer, M.; C. Hase; P. Meuwly; J.P. Metraux and G. Defago (1994). Induction of systemic resistance of tobacco to tobacco necrosis virus by the root colonizing Pseudomonas fluorescens strain CHAO: influence of the gacA gene and of pyoverdine production. Phytopathology, 84:139-146.

Mohamed, A. A.; F. A. Saeed; M. H. A. Hassan and M. M. El-Fawy (2008). Efficacy of biological control in reducing the incidence of wilt and damping-off diseases in cumin. Egypt j. of Appl. Sci., 23 (11): 46-57.

Morsy, K.M.; M.F. Abdel-Monaim and M. M. Mazen (2011). Use of Abiotic and Biotic Inducers for Controlling Fungal Diseases and Improving Growth of Alfalfa. World Journal of Agricultural Sciences, 7 (5): 566-576.

Nelson, P. E., T. A. Toussoun and W. F. O. Marasas, (1983). Fusarium species: An Iullustrated Manual for Identification. Pennsyllvania State University Press, University Park, Pennsylvannia, USA.

Pal, R.; K. Chakrabarti; A. Chakraborty and A. Chowdhury (2005). Pencycuron application to soils: Degradation and effect on microbiological parameters. Chemosphere, 60 (11): 1513-1522.

Park, K.S. and J.W. Kloepper (2000). Activation of PR-1 a promoter by rhizobacteria that induce systemic resistance in tobacco against Pseudomonas syringae pv. tabaci. Biol. Control, 18:2-9.

Paz-lago, D.; A. B. Jr; A. Gutierrez; A. Borges; G. Cabrera; M. A. Ramirez and A. Falcon (2000). Tomato- Fusarium oxysporum interactions: Ii-Chitosan and msb induced resistance against $\mathrm{FOL}$ in young tomato plants. Cultivos Tropicales, 21(4), 17-20.

Prabhukarthikeyan, S. R., U. Keerthana, S. Archana and T. Raguchander (2017). Induced resistance in tomato plants to Helicoverpa armigera by mixed formulation of Bacillus subtilis and Beauveria bassiana. Research Journal of Biotechnology, 12 (10): 53-59.

Shen, S. H.; P. Chretien; L. Bastien and S. N. Slilaty (1991). Primary sequence of the glucanase gene from Oerskovia xanthineolytica: expression and purification of the enzyme from Escherichia coli. J Biol Chem., 15: 1058-1063.

Sivan, A. and I. Chet (1986). Biological control of Fusarium spp. in cotton, wheat and muskmelon by Trichoderma. Journal of Phytopathologische Zeitschrift, 116: 39-47.

Srivastava, R.; A. Khalid; U. S. Singh and A. K. Sharma (2010). Evaluation of arbuscular mycorrhizal fungus, fluorescent Pseudomonas and Trichoderma harzianum formulation against Fusarium oxysporum f.sp. lycopersici for the management of tomato wilt. Biol. control, 53(1): 24-31.

Surekha, C. H.; N. R. R. Neelapu, B. Siva Prasad and P. Sankar Ganesh (2014). Induction of defense enzymes and phenolic content by Trichoderma viride in vigna mungo infested with Fusarium oxysporum and Alternaria alternata. International Journal of Agricultural Science and Research, 4 (4): 31-40.

Tanksley, S. D. and T. J. Orton (1986). Isozymes in plant genetics and breeding. Part A (eds.), Elsevier Sci. Puplishers B. V. New York pp. 500.

Vinale, F.; K. Sivasithamparam; E. L. Ghisalberti; R. Marra; S. L. Woo and M. Lorito (2008). Tricho- 
derma-plant-pathogen interactions. Soil Biol. Biochem., 40:1-10.

Wang, H.F., (1996). Studies of manganese superoxide dismutase gene of Ganoderma. Master thesis, Graduate institute of Agricultural Chemistry, National Taiwan University, Taipei, Taiwan. R.O.C.
Yedidia, I.; N. Benhamou and I. Che (1999). Induction of defense responses in cucumber plants $(\mathrm{Cu}$ cumis sativus L.) by the biocontrol agent Trichoderma harzianum. Applied and Environmental Microbiology, 1061-1070. 
تأثثير بعض المبيدات الحيوية على مرض الأبول الفيوزاريومى وعلى إختلافات التعبير الجيني

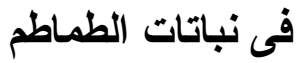

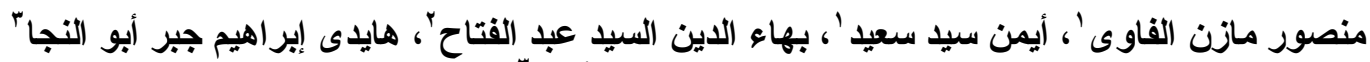

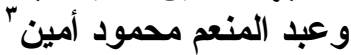

$$
\begin{aligned}
& \text { ' قسم النبات الزر اعى (أمر اض نبات) كلية الزر اعة - جامعة الأزهر - أسيوط- مصر . }
\end{aligned}
$$

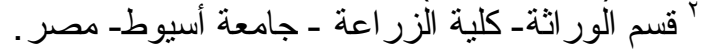

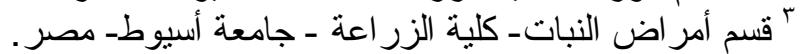

تم تقييم فعالية معاملة النربة بنو عين من المبيدات الحيويـة التجاريـة وهى البيو زد و البيو

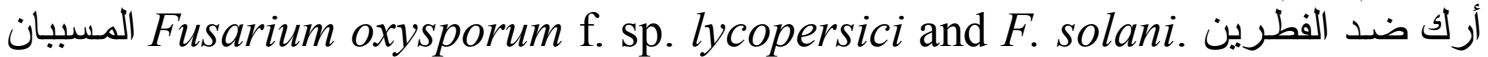

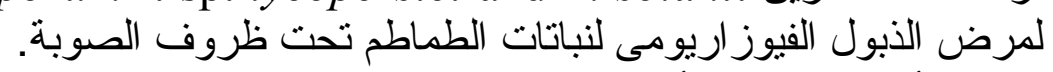

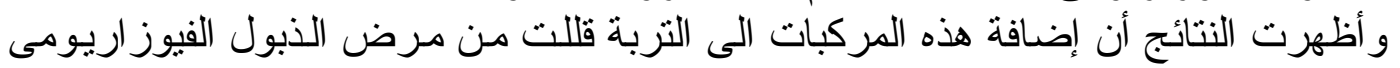

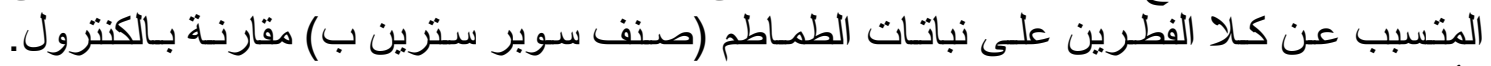

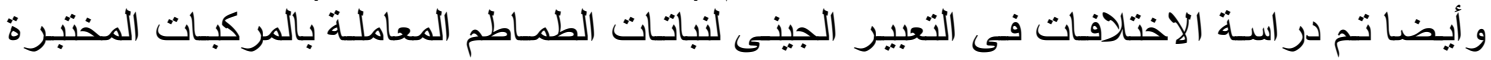

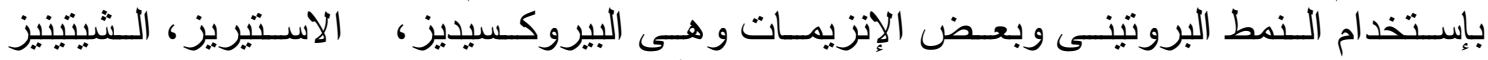

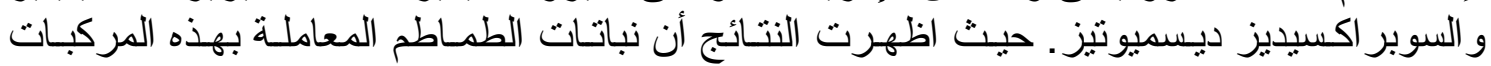

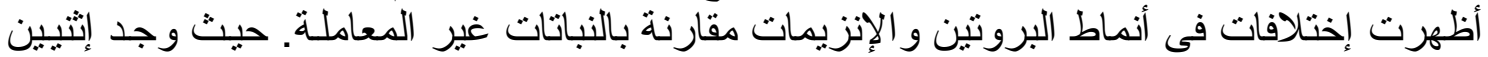

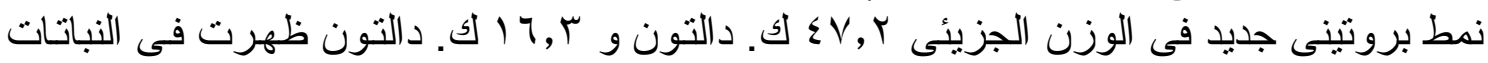

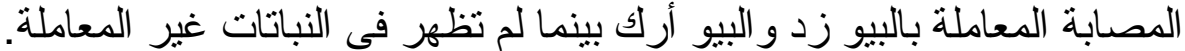

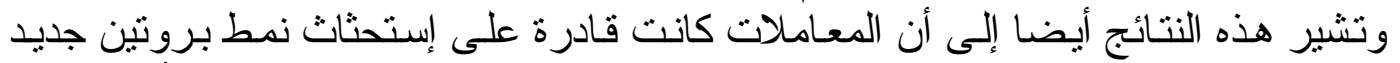

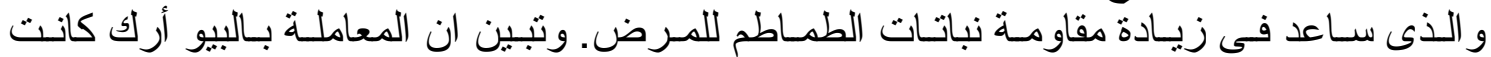

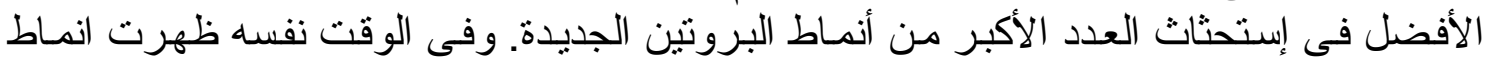

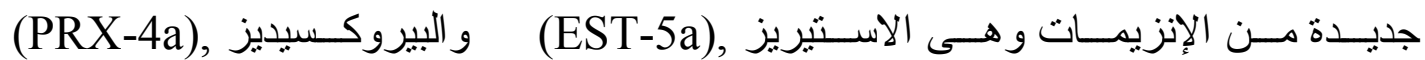
و الثنيتينيز (Chit-5b) و السوبر اكسيديز ديسميو تيز (SOD-1a) فى كل المعاملات بينما لم تظهر (EST)

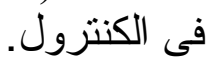

